\title{
EFEKTIVITAS PELATIHAN MANAJEMEN STRES DALAM PENURUNAN STRES KERJA PADA ANGGOTA BADAN SEARCH AND RESCUE NASIONAL (BASARNAS) KOTA PADANG
}

\author{
Mutiara Ramadhani ${ }^{1}$, Widia Sri Ardias ${ }^{2}$ \\ ${ }^{12}$ UIN Imam Bonjol Padang \\ mutiaramadhani832@gmail.com
}

\begin{abstract}
The purpose of this study was to see what level of stress the work of members of the Padang City BASARNAS before being given training, and after being given stress management training. Furthermore, the research also highlighted the influence of stress management training in reducing work stress on members of the Padang City BASARNAS. The method used in this study is a quantitative method of experimental design with the technique of T-test test analysis with paired sample T-test that is processed with SPSS version 20.0 for Windows. The independent variables in this study were stress management training and work stress dependent variables. The population of this study are members of the Padang City BASARNAS. Using purposive sampling while the data collection techniques in this study use psychological measuring instruments in the form of scales, the scale of work stress totaling 24 items. The results showed that before being given stress management training 4 members of the Padang City BASARNAS had a high stress level category, and 4 people in the moderate category. After being given stress management training the stress level of BASARNAS members in Padang decreased by 5 people in the medium category, and 3 people in the low category. Effective stress management training reduces work stress on members of the Padang City BASARNAS as evidenced by the significant index results of 0,000 $(<0.050)$. Similar training in areas of work with the potential for high levels of work stress is recommended to be carried out so that employee performance can be optimized due to efforts to manage employee stress.
\end{abstract}

Keywords: Training, Stress Management, Job Stress, BASARNAS

\begin{abstract}
ABSTRAK
Tujuan dari penelitian ini adalah untuk melihat berapa tingkat streskerja anggota BASARNAS Kota Padang sebelum diberikan pelatihan, dan setelah diberikan pelatihan manajemen stress. Selanjutnya penelitian juga menyeroti adakah pengaruh pelatihan manajemen stres dalam penurunan stres kerja pada anggota BASARNAS Kota Padang. Metode yang digunakan dalam penelitian ini adalah metode kuantitatif rancangan eksperimen dengan teknik analisis uji T-test dengan paired sample T-test yang diolah dengan program SPSS versi 20.0 forwindows. Variabel bebas dalam penelitian ini adalah pelatihan manajemen stres dan variabel terikatnya stres kerja. Populasi dari penelitian ini adalah anggota BASARNAS Kota Padang. Penarikan sampel menggunakan purposive sampling sementara teknik pengumpulan data dalam penelitan ini menggunakan alat ukur psikologi berbentuk skala, skala stres kerja berjumlah 24 item. Hasil penelitian menunjukkan bahwa sebelum diberi pelatihan manajemen stress 4 orang anggota BASARNAS Kota Padang memiliki tingkat stres ada kategori tinggi, dan 4 orang pada kategori sedang. Setelah diberikan pelatihan manajemen stres tingkat stres anggota BASARNAS Kota Padang menurun 5 orang dikategori sedang, dan 3 orang di kategori rendah. Pelatihan manajemen stress efektif menurunkan stres kerja pada anggota BASARNAS Kota Padang yang dibuktikan dengan hasil indeks signiikan sebesar 0,000 $(<0,050)$. Pelatihan serupa pada bidang kerja dengan potensi tingkat stres kerja tinggi disarankan untuk dilaksanakan sehingga kinerja karyawan lebih dapat dioptimalkan karena adanya usaha untuk mengelola stres karyawan.
\end{abstract}

Kata Kunci: Pelatihan, Manajemen Stres, Stres Kerja, BASARNAS 


\section{PENDAHULUAN}

Indonesia dikenal sebagai negara kepulauan. Letak geografis Indonesia yang diapit oleh dua benua dan dua samudera menjadikan Indonesia negara yang strategis. Hal Ini memberikan dampak positif dan negatif bagi negara Indonesia sendiri. Secara geologis Indonesia terletak pada pertemuan tiga lempeng di dunia yaitu lempeng Indo-Australia, lempeng Eurasia, dan lempeng Pasifik. Letak tersebut mempengaruhi bagaimana kondisi alam Indonesia, sehingga Indonesia dikenal dengan negara rawan bencana alam (Zalukhu, 2013).

Data yang di himpun oleh Badan Nasional Penanganan Bencana (BNPB) pada tahun 2018 menyatakan sekitar 3.400 kejadian, dengan rincian 871 kali banjir, 615 kali tanah longsor, 1.113 kali puting beliung, 130 kali kekeringan, dan 527 kali kebakaran lahan (http://dibi.bnpb.go.id/ diakses pada 14 Mei 2019). Salah satu kawasan rawan bencana adalah Sumatera Barat. Dikutip dari website Pemburu Ombak wilayah (https://www. pemburuombak. Com /berita /nasional /item /1750-indonesia- negara-indah-sekaligus-negara-rawan-gempa-bumi diakses pada: 05 Oktober 2018) menyebutkan bahwa, daerah rawan bencana tsunami di Indonesia antara lain Nanggroe Aceh Darussalam, Sumatera Utara, Sumatera Barat, Bengkulu, Lampung, Banten, Jawa barat bagian Tengah dan Selatan, Jawa Timur bagian Selatan, Bali, Nusa Tenggara Timur, Sulawesi Utara, Sulawesi Tengah, Sulawesi Selatan, Maluku Utara, Maluku Selatan, Biak Danyapen (Papua/Irian), Balikpapan dan Sekurau (Kalimantan Timur), Palu (Sulawesi Tengah), Talaud (Sulawesi Utara), serta Kendari (Sulawesi Tenggara).

Berdasarkan data Badan Nasional Penanggulan Bencana Daerah (BNPD) dalam lima tahun terakhir terdapat sekitar 350 kejadian di Sumatera Barat, dengan rincian kejadian seperti berikut, 161 kali banjir, 84 kali tanah longsor, 107 kali puting beliung, 3 kali kebakaran hutan, dan sebanyak 8 kali gempa bumi (http://dibi.bnpb.go.id/diakses pada 17 Mei 2019). Dampak dari bencana alam tersebut, kerusakan yang terjadi sekitar 2.821 kerusakan rumah dan fasilitas umum, 3 orang meninggal dunia dalam bencana tersebut, 68 orang luka-luka, dan yang 
terdampak serta mengungsi sebanyak 4.392 orang (http://dibi.bnpb.go.id/diakses pada 17 Mei 2019).

Salah satu badan yang terlibat bertugas ketika terjadinya bencana adalah Badan Search and rescue Nasional (BASARNAS). Badan SAR Nasional adalah lembaga yang bergerak dalam bidang penacarian dan pertolongan atau search and rescue. Lembaga ini langsung di bawah naungan presiden Indonesia. Menurut Zalukhu (2013) BASARNAS adalah lembaga pemerintahan non kementrian yang bertugas melaksanakan tugas pemerintahan dibidang pencarian dan pertolongan. BASARNAS memiliki tugas pokok dalam pembinaan, pengkordinasian dan pengendalian potensi search and rescue. Kegiatan search and rescue terhadap orang atau material yang hilang, di khawatirkan hilang atau menghadapi bahaya dalam pelayaran dan penerbangan serta memberikan bantuan dalam bencana dan musibah lainnya.

Peraturan menteri perhubungan Nomor KM.43T tahun 2005 tentang Organisasi dan tata kerja Departemen Perhubungan, BASARNAS mempunyai tugas pokok melaksanakan pembinaan, pengkoordinasian, dan pengendalian potensi Search and rescue. Kegiatan search and rescue terhadap orang dan material yang hilang atau dikhawatirkan hilang, atau menghadapi bahaya pelayaran dan atau penerbangan, serta memberikan bantuan search and rescue dalam penanggulangan bencana dan musibah lainnya sesuai dengan peraturan SAR Nasional dan Internasional.

Melihat urgensi dari tugas di atas, maka tim BASARNAS memiliki berbagai tuntutan untuk tetap siaga dalam 24 jam. Berdasarkan peraturan kepala BASARNAS Nomor 12 Tahun 2013 yang mengatur mengenai hari kerja dan jam kerja ditetapkan hari kerja BASARNAS perminggu adalah 5 hari yaitu senin sampai jumat dengan jam kerja 9 jam perhari masuk pukul 7.30 keluar pukul 16.30 waktu setempat. Kemudian dalam peraturan Presiden Republik Indonesia Nomor 99 Tahun 2007 tentang Badan SAR pasal 36 menjelaskan dalam hal tidak terjadi musibah pelayaran atau 
penerbangan atau bencana dan musibah lainnya, BASARNAS melaksanakan siaga selama 24 jam secara terus menerus, hal ini merupakan pemicu munculnya stres kerja pada anggota BASARNAS.

Setiap wilayah memiliki BASARNAS, begitupun di Kota Padang Sumatera Barat. Sistem kerja BASARNAS di kota Padang tidak jauh berbeda dengan kondisi di nasional. Hal tersebut mengacu pada aturan yang telah ditetapkan oleh pemerintah dalam perundangan- undangan maupun ketetapan presiden yang menaungi langsung BASARNAS. Berdasarkan tinjauan lapangan yang dilakukan pada September 2018 lalu, diketahui bahwa anggota BASARNAS Kota Padang merasakan bosan selama bekerja, dan cenderung merasa stres dalam pekerjaannya, karena tuntutan untuk standbye selama 24 jam. Sistem kerja BASARNAS Kota Padang sesuai dengan jam kantor pada umumnya, hanya saja anggota rescue melakukan siaga selama 24 jam dengan sistem kerja sift, anggota rescue BASARNAS Kota Padang di bagi menjadi tiga kelompok dan melakukan siaga 24 jam secara bergantian perkemlompok. Hasil wawancara yang di lakukan diketahui bahwa, motivasi mereka bekerja tidak semuanya karena jiwa sosial yang tinggi, melainkan karena untuk memenuhi kebutuhan hidup.

Pada saat tinjauan lapangan yang dilakukan September 2018 lalu, salah seorang dari anggota BASARNAS Kota Padang, meminta untuk diadakan kegiatan dalam menurunkan rasa bosan dan stres kepada anggota BASARANAS Kota Padang. Salah satu penyebab stres adalah pekerjaan, stres karena pekerjaan di sebut dengan stres kerja. Stres kerja adalah keadaan tertekan pada seseorang terkait dengan pekerjaannya dan mempengaruhi keadaan emosi dan respon fisiknya. Menurut Mangkunegara (2008:93) stres kerja adalah suatu perasaan yang menekan atau tertekan yang dialami karyawan dalam menghadapi pekerjaannya. Menurut Robins (Wijayanti, 2016:25) gejala - gejala terjadinya stres kerja diantaranya, gejala fisiologis, gejala psikologis, dan gejala perilaku.Faktor penyebab terjadinya stres kerja adalah faktor lingkungan, faktor organisasi, dan faktor individu. Stres kerja berdampak pada subjektif, perilaku, kognitif, fisiologis dan juga organisasi. 
Melihat hasil dari tinjauan lapangan dan wawancara yang dilakukan, anggota BASARNAS cukup sering merasa tertekan dengan tuntutan pekerjaannya serta adanya permintaan dari anggota BASARNAS Kota Padang untuk diadakan kegiatan yang dapat menghilangkan rasa bosan dan menurunkan stres kerja. Peneliti juga merujuk dari penelitian sebelumnya, maka peneliti tertarik untuk meneliti pengaruh pelatihan manajemen stres terhadap penurunan stres kerja pada anggota BASARNAS Kota Padang.

Menurut KBBI pelatihan adalah proses, cara, perbuatan melatih. Pelatihan adalah pengalaman belajar terstruktur dengan tujuan mengembangkan kemampuan menjadi keterampilan khusus, pengetahuan atau sikap tertentu. Pelatihan adalah proses pembelajaran yang melibatkan perolehan keahlian, konsep, peraturan atau sikap untuk meningkkatkan kinerja tenaga kerja. Menurut Dessler (2005) dalam Sulaefi (2017:9) pelatihan adalah proses dimana orang -orang mencapai kemampuan tertentu untuk membantu mencapai tujuan organisasi. Pelatihan lebih cenderung berorientasi jangka pendek, pelatihan berpengaruh pada kinerja, dan jika pelatihan yang dilakukan oleh perusahaan berhasil maka kinerja karyawan akan meningkat dengan sendirinya. Pelatihan tidak hanya mengembangkan kemampuan karyawan tetapijuga mempertajam kemampuan berfikir dan kreativitas dalam rangka mengambil keputusan yang lebih baik dalam waktu dan cara yang lebih produktif.

Robbins (2008) menjelaskan bahwasannya metode pelatihan merupakan metode yang cukup efektif untuk meningkatkan motivasi, mengubah struktur kognitif, memodifikasi sikap,dan menambah keterampilan berperilaku. Betcherman (1998) dalam Sharah dan Yuniasanti (2018) juga menjelaskan bahwasannya pelatihan sebagai perlakuan untuk modifikasi perilaku yang direncakan dan sistematis melalui kegiatan pembeajaran untuk menghasilkan peserta mencapai tingkat pngetahuan, keterampilan, kompetensi dan kemampuan untuk melaksanakan pekerjaan mereka secara efektif. Jadi dapat kita simpulkan bahwa pelatihan adalah suatu prosesyang 
dirancang untuk meningkatkan keahlian, pengetahuan, dan pengalaman, atau perubahan sikap seorang.

Beberapa jenis pelatihan yang dapat diselenggarakan didalam organisasi yaitu pelatihan kemampuan (skill training), pelatihan ulang ( retraining), pelatihan lintas fungsional (CrossFunctional Training), pelatihan tim dan pelatihan kreativitas.

Adapun Cole (2002) dalam Sharah dan Yuniasanti (2018) menegaskan bahwa tujuan utama pelatihan adalah untuk memperoleh dan meningkatkan pengetahuan, keterampilan, kompetensi dan sikap terkait tugas pekerjaan. Simamora (1999) dalam Dyastuti (2018) juga memaparkan tujuan dari pelatihan yaitu, untuk memperbaiki kerja,untuk memutakhirkan keahlian para karyawan, membentuk sikap karyawan dan memenuhi kebutuhan perencanaan sumbr daya manusia. Pelatihan menyajikan setidaknya 3 fungsi penting untuk organisasi yaitu pemeliharaan, sosialisasi dan motivasi (https://www.academia.edu/46946 76/Pelatihan_dalam_Psikologi_In dustri_dan_Organisasi).

Menurut Murphy (Bahrul Ilmi 2002:35) manajemen stres adalah suatu teknik yang di desain untuk membantu para pekerja dalam merubah pemikiran mereka terhadap situasi stres yang tinggi atau mengetahui gejala stres secara efektif. Sedangkan menurut Munandar (2001) majemen stres berarti berusaha mencegah timbulnya stres, meningkatkan ambang stres dari indivu dan menampung akibat fisiologis dari stres tersebut. Schafer (Segarahayu, 2015:5) menyebutkan manajemen stres adalah suatu prograam untuk pengontrolan stres dimana bertujuan untuk mengenal penyebab stres dan mengetahui teknik-teknik mengelola stres, sehingga orang lebih baik dalam menguasai stres dalam kehidupan. Dari beberapa definisi manajemen stres menurut para ahli diatas dapat disimpulkan bahwa manajemen stres adalah suatu kemampuan untuk mengendalikan diri, berusaha mencegah timbulnya stres dan meningkatkan ambang stres.

Stres Menurut Meichanbaum dan Jaremko dalam Taylor (1995 dalam Hakim, Tantiani, Shanti, 2017:76) ada tiga tahap dalam manajemen stres yaitu: 1) Tahap pertama, partisipan 
manajemen stres belajar mengenal stres dan bagaimana mengenali sumber stres yang muncul dalam kehidupannya; 2) Tahap kedua, partisipan mendapatkan dan mempraktekan keterampilan coping stress; dan 3) Tahap ketiga, partisipan mempraktekkan teknik manajemen stres pada suatu peristiwa dan di lihat kefektifannya

Stres kerja atau work stress sering juga disebut dengan job stress, pada dasarnya stres kerja tidak berbeda dengan stres yang berada diluar lingkungan organisasi namun sifaatnya trjadi ditempat kerja. Stres kerja adalah suatu kondisi tertekan pada seseorang terkait dengan pekerjaannya sehingga mempengaruhi emosi dan respon fisiknya. Manktelow (2007:14) menjelaskan stres adalah kumpulan hasil, respons, jalan dan pengalaman yang berkiatan, yang di sebabkan oleh berbagai stressor. Menurut Mangkunegara (2008) stres kerja adalah suatu perasaan yang menekan atau tertekan yang dialami karyawan dalam menghadapi pekerjaannya.

French, Rogers, \& Cobb (Wijono, 2010) mendefiniskan stres kerja adalah“ A misfit between a person's skill and abilities and demans of the job misfit in term of person's need's supplited by the job environment". Van Harrison dan Pinneau merubah definisi itu menjadi "Any characteristic of the job environment which process a threat to the individual' (Wijono,2010). Smith mengemukakan bahwa konsep stres kerja dapat ditinjau dari beberapa sudut, yaitu stres kerja merupakan hasil dari keadaan tempat kerja, stres kerja merupakan hasil dari dua faktor organisasi, yaitu keterlibatan tugas dan dukungan organisasi, selanjutnya stres kerja terjadi karena faktor kemampuan melakukan tugas, stres kerja juga akibat dari waktu kerja yang berlebihan serta tantangan yang muncul dari stres kerja.

Menurut Anoraga (2001:108), stres kerja adalah bentuk tanggapan seseroang, baik fisik maupun mental terhadap suatu perubahan di lingkungannya yang di rasakan menganggu dan mengakibatkan dirinya terancam. Robins ( Tunjungsari, 2011:4) stres kerja adalah kondisi yang muncul dari interaksi antara manusia dan pekerjaan serta dikarekteristikan oleh perubahan manusia yang memaksa mereka untuk menyimpang fungsi normal mereka. Mangkunegara (2008) 
menjelaskan stres kerja adalah perasaan karyawan dalam menghadapi pekerjaan. Berdasarkan pengertian yang dikemukan oleh para ahli dapat kita ambil kesimpulan bahwa stres kerja adalah gangguan pada tubuh dan pikiran serta perasaan tertekan yang sebabkan oleh tuntutan tempat kerja yang berlebihan.

Aspek-aspek Stres Kerja Menurut Schultz dan Robbins (Almasitoh, 2011) yaitu deviasi fisiologis, deviasi psikologis dan deviasi perilaku. Faktor -Faktor yang mempengaruhi stres kerja Menurut Robins (Wijayanti, 2016:24) yaitu faktor lingkungan, faktor organisasional (seperti tuntutan tugas, tuntutan peran, tuntutan antar pribadi, struktur organisasi dan kepemimpinan)

Spector dalam Marchelia (2014:135) menjelaskan beberapa penyebab stres antara lain role ambiguity, role conflict, role ambiguity, workload, control. Lazimnya Individu hanya bekerja 40 sampai 50 jam sepekan. Pengalaman dan masalah yang di jumpai orang di luar jam kerja yang lebih dari 120 jam tiap minggu dapat berpengaruh ke pekerjaan, maka kategori akhir yang mencakup faktor faktor dalam individual yaitu: masalah keluarga, masalah ekonomi pribadi.

Badan SAR Nasional adalah lembaga yang bergerak dalam bidang penacarian dan pertolongan atau search and rescue. Lembaga ini langsung di bawah naungan presiden. Menurut Zalukhu (2013:3) Badan SAR Nasional adalah lembaga pemerintahan non kementrian yang bertugas melaksanakan tugas pemerintahan di bidang pencarian dan pertolongan. Undang - undang nomor 29 tahun 2014 tentang pencarian dan pertolongan, badan pencarian dan pertolongan atau yang lazim dikenal dengan BASARNAS adalah lembaga non kementerian yang menyelenggarakan urusan pemerintahan di bidang pencarian dan pertolongan.

\section{METODE PENELITIAN}

Jenis penelitian ini adalah penelitian kuantitatif dengan rancangan penelitian eksperimen, menggunakan desain penelitian one group pretest posttest. diawal penelitian dilakukan pengukuran terhadap VT (variabel terikat), kemudian di berikan treatmen, setelah diberikan perlakuan dilakukan 
kembali pengukuran terhadap VT (variabel terikat) dengan skala atau alat ukur yang sama.Populasi dalam penelitian ini adalah Anggota BASARNAS Kota Padang yang berjumlah 35 orang. pengambilan sampel pada penelitian ini menggunakan teknik accidental sampling, yaitu penentuan sampel berdasarkan kebetulan, jadi pengambilan sampling dalam penelitian ini berdasarkan berapa sampel yang ada di kantor pada pelaksanaan pelatihan, dan yang berada di kantor pada saat pelatihan ada sebanyak 8 orang. Teknik pengumpulan data dalam penelitian ini adalah dengan wawancara dan pembagian skala, sedangakan teknik analisis data dalam penelitian ini menggunakan paired sample T-test SPSS 20.0 for windows.

\section{HASIL}

Berdasarkan data yang diperoleh dari pengolahan data menggunakan SPSS Versi 20.00 Forwindows terlihat bahwa terjadi perubahan tingkat stres pada anggota BASARNAS Kota Padang. Sebelum diberi pelatihan tingkat stres anggota BASARNAS Kota Padang terlihat seperti tabel dibawah ini :

\section{Tabel 1. tingkat stres sebelum pelatihan}

\begin{tabular}{|c|c|}
\hline Subiek & $\begin{array}{c}\text { Tingkat stres } \\
\text { sebelum } \\
\text { pelatihan }\end{array}$ \\
\hline YD & 88 \\
\hline YS & 79 \\
\hline E & 90 \\
\hline AW & 74 \\
\hline MI & 90 \\
\hline DA & 84 \\
\hline R & 77 \\
\hline SZ & 81 \\
\hline
\end{tabular}

(Sumber : Hasil Penelitian) 
Setelah dilakukan pelatihan tingkat stress anggota BASARNAS Kota Padang terlihat seperti tabel dibawah ini :

Tabel 4.11 tingkat stres sesudah pelatihan

\begin{tabular}{|c|c|}
\hline Subjek & $\begin{array}{c}\text { Tingkat stres } \\
\text { sesudah pelatihan }\end{array}$ \\
\hline YD & 69 \\
\hline YS & 53 \\
\hline E & 80 \\
\hline AW & 62 \\
\hline MI & 71 \\
\hline DA & 80 \\
\hline R & 65 \\
\hline SZ & 58 \\
\hline
\end{tabular}

\section{DISKUSI}

Berdasarkan data yang diperoleh dari hasil penelitian, menunjukkan bahwa semua subjek yang diteliti mengalami penurunan stres kerja setelah mengikuti pelatihan manajemen stres. Sebelum diberikan pelatihan manajemen stres 4 orang subjek memiliki stres kerja pada kategori tinggi, dan 4 orang lagi memiliki stres kerja pada kategori sedang. Setelah diberikan pelatihan manajmen stres, terjadi penurunan yakni 5 orang memiliki stres kerja pada kategori sedang, dan 3 orang memiliki stres kerja kategori rendah.

Dari hasil analisis data yang diperoleh dapat diketahui bahwa pelatihan manajemen stres berpengaruh dalam penurunan stres kerja. Hal ini dapat terlihat dari perbedaan nilai mean pretest dan postest, nilai pretest sebesar 83,50 setelah di berikan treatment didapatkan nilai postest sebesar 65,13 , terlihat penurunan nilai sebesar 18,37 . Kemudian dilihat dari signifikannya 0,000 yang berarti telah terjadi pengaruh terhadap subjek dalam penurunan stres kerja setelah diberikan pelatihan manajemen stres. 


\section{KESIMPULAN DAN SARAN}

Penelitian ini sekaligus membuktikan bahwa modul pelatihan manajemen stres yang dibuat untuk penelitian ini terbukti dapat direkomendasikan untuk dilaksanakan kembali pada pekerjaan lain dengan potensi tingkat stres kerja yang tinggi. Pelatihan manajemen stres kerja merupakan salah satu usaha pengelolaan stres karyawan yang dilakukan perusahaan sehingga diharapkan ketika tingkat stres terkelola dengan baik maka kinerja karyawan juga dapat ditingkatkan.

\section{DAFTAR PUSTAKA}

Munandar. (2001). Psikologi Industri dan Organisasi. Depok: UIPress

Abdurrahmat, Fathoni. (2005). Metodologi Penelitian \& Teknik Penyusunan Skripsi. Jakarta: Rineka Cipta

Almasitoh, U. H. (2011). Stres Kerja Ditinjau dari Konflik Peran Ganda dan Dukungan Sosial Pada Perawat. Psikoislamika - Jurnal Psikologi Volume 1 Klaten Universitas Widya Dharma

Anoraga, Panji. (2001). Psikologi Kerja. Jakarta: Rineka Cipta

Mangkunegara, Anwar Prabu. (2003). Perencanaan dan Pengembangan Sumber Daya Manusia. Bandung: Refika Aditama . (2005). Sumber Daya Manusia Perusahaan. Bandung: Remaja Rosdakraya

Ardias, S.W. (2015). Peran Perceived Organizational Support Sebagai Moderator Pada Hubungan Job Stress Dengan Intensi Turnover.Tesis

Arikunto, Suharsimi. (2006). Prosedur Penelitian Suatu Pendekatan Praktik. Jakarta : Rineka Cipta . (2009). Manajemen Penelitian. Jakarta: Rineka Cipta

Azwar, Saifuddin. (2012). Penyusunan Skala Psikologi. Yogyakarta : Pustaka Belajar

Bahrul, Ilmi. (2002). Pengaruh Stres Kerja Terhadap Prestasi Kerja dan Identifikasi Manajemen Stres yang di gunakan perawat di ruang Rawat INAP RSUD Ulin Banjarmasin. Tesis tidak di terbitkan

Davis, Keith \& Newstrom, J.W. (1985). Perilaku Dalam Organisasi. Jakarta : Erlangga Hakim,

Rahmita, Ereka Gamma. (2017). Efektifitas Pelatihan Manajemen Stres Pada Mahasiswa. Jurnal Sains Psikologi. Jilid 6, Nomor2

Handoko, T. Hani. (2001). Manejemen Personalia dan Sumber Daya Manusia. Yogyakarta: BPFE Yogyakarta

Latipun. (2006). Psikologi Eksperimen Edisi kedua. Malang: UMM Press

Manktelow, James. (2007). Mengendalikan Stres. Jakarta : Erlangga

Marchelia. (2014). Stres Kerja Ditinjau dari Shift Kerja Karyawan. Jurnal Ilmiah Psikologi Terapan Vol 02

Pramudiyanti, Kusuma Anggita. (2012). Pengaruh pelatihan manjemen stres terhadap penurunan stres kerja padaperwat rumah sakit jiwa. Tesis Tidak di terbitkan

Priyatno, D. (2012). Belajar Cepat Olah Data Statistik dengan SPSS. Yogyakarta: Andi

Robbin. Stephen P.(2006). Perilaku Organisasi. Edisi kesepuluh. Jakarta: PT Indeks Kelompok Gramedia

Sahrah. A. (2018). Aktivitas Pelatihan Pemberian Dukungan Sosial Pada Walinapi Dengan Metode Bermain dan Permainan Peran. Jurnal Psikologi Vol 45 No2. 
Segarahayu, Dianita Rizky. Pengaruh Manajemen stres terhadap penurunan tingkat stres pada narapidana di LPW Malang. Jurnal tidak di terbitkan

Seniati, L. (2005). Psikologi Eksperimen. Jakarta

Setiawan, Budi. (2015). Teknik Praktis Analisis Data Penelitian Sosial \& Bisnis dengan SPSS. Yogyakarta: Andi Offet

Siregar, Syofian. (2010). Statistika Deskriptif Untuk Penelitian. Jakarta : Rajawali Pers

Sudjana. (2005). Metode Statistika. Bandung: Trasito

Sugiyono. (2007). Metode Penelitian Kuantitatif Kualitatif Dan R\&D. Bandung: Alfabeta (2007). Statistika Untuk Penelitian. Bandung : Alfabeta

. (2008). Metode Penelitian Kuantitatif Kualitatif Dan R\&D. Bandung: Alfabeta

(2013). Metode Penelitian Kuantitatif Kualitatif Dan R\&D. Bandung : Alfabeta

Sulaefi. (2017). Pengaruh Pelatihan dan Pengembangan Terhadap Disiplin Kerja Dan Kinerja Karywan. Jurnal Manajemen Dan Kewirausahaan Vol 5 No 1

Tunjungsari, Peni. (2011). Pengaruh Stres kerja terhadap kepuasan kerja karyawan pada kantor pusat PT. Pos Indonesia (PERSERO) Bandung. Bandung : Universitas Komputer Indonesia. Jurnal Manajemen

Wartono, Tri. (2017). Pengaruh Sters Kerja Terhadap Kinerja Karyawan (studi pada karyawan Majalah Mother and baby). Jurnal Ilmiah Prodi Manajemen Unuiversitas Pamulang. Volume 4 No. 2

Wijayanti, Puji Husna. (2016). Hubungan Antara persepsi lingkungan dengan stres kerja pada mekanik honda. Skripsi tidak di terbitkan

Wijono, Sutarto. (2010). Psikologi Industri dan Organisasi. Jakarta

Zalukhu, Irwan \& Surip, Ngadino. (2013). Pengaruh Kecerdasan Emosional, Iklim Organisasi dan Stres Kerja Terhadap Kinerja Pegawai (Studi Kasus Kantor BASARNAS Jakarta). Da 